\title{
THE FATE OF THE BULGARIAN WORD ДЕTO IN SLOVENE LITERARY TRANSLATIONS
}

\author{
Robert GROŠELJ \\ University of Ljubljana, Slovenia \\ E-mail: robert.groselj@ff.uni-lj.si
}

\begin{abstract}
The aim of the article is to determine and to analyse translation equivalents of the Bulgarian lexical item demo in Slovene translations of five Bulgarian novels. After the introductory overview of the uses of demo (with a contrastive Bulgarian-Slovene perspective) and the functional-semantic analysis of all the occurrences of demo (including само дето and освен дето) in the novels analysed, their Slovene translation counterparts were extracted and analysed functionally, semantically, as well as quantitatively. The most frequent function of demo in the analysed novels is that of the absolute relativizer, followed by demo as a causal and a locative conjunction, and a relativizer with a concessive meaning; demo is also a part of two complex conjunctions, with само demo indicating limitation-contrast or unfoundedness, and oсвен дето signalling limitation. In addition, дето is found in the parenthetical clause дето се казва 'as the saying goes'. The translation equivalents show a higher diversity in comparison with the source text forms. Bulgarian demo, caмo demo and освен дето have - within separate functional-semantic categories - a broad array of functional-semantic, lexical and structural Slovene translation equivalents: pronouns (mainly relative), various conjunctions, omissions, modal particles, adverbs, and clauses. The analysis has shown that дето (with само дето and освен дето) does not have an analogous lexical counterpart in Slovene. Moreover, translators frequently depart from the semantic, syntactic and stylistic features of the source text.
\end{abstract}

KEYWORDS: Bulgarian demo, semantic-functional features, contrastive analysis, translation analysis, translation equivalent, Slovene

\section{Introduction}

The Bulgarian word demo is an intriguing lexical item - it is a connector with a vast array of uses, as indicated by various Bulgarian linguistic works (cf. Gadzheva, 2015, pp. 409 - 410), a balcanism with equivalents in other languages of the Balkan Sprachbund and, to a degree, in Shtokavian (Sandfeld, 1968, p. 107; Gadzheva, 2015, p. 409; cf. Nitsolova, 1998, pp. $84-85$ ), it is marked as an element of the spoken language, although it is found in several, not only spoken, varieties of contemporary Bulgarian (Dacheva and Tisheva, 2005, pp. 390 - 391; Gadzheva, 2015, p. 409). Since demo is such an interesting connector - from a functional-semantic, typological and language variety point of view - the main aim of the article is to determine and analyse its Slovene translation equivalents, based on five Bulgarian novels and their Slovene translations. In doing so, the article will complement the existing (relatively limited) contrastive studies between Slovene and Bulgarian, especially the contrastive analyses of the conjunction $\partial a / d a$ 'that' in the two languages by M. Deyanova (for an overview see Valčanova, 2002, pp. 393 - 394).

\section{Corpus and method}

The study is based on text examples from five Bulgarian novels (published in the second half of the $20^{\text {th }}$ c.) and their Slovene translations: Тютюн (Tуиtyun) by Dimitar Dimov (DD), Федерация на династронавтите (Federatsiya na dinastronavtite) by Haim Oliver (HO), Пътуване към себе си (Patuvane kam sebe si) by Blaga Dimitrova (BD), Нощем с белите коне (Noshtem s belite kone) by Pavel Vezhinov (PV), and Естествен роман (Estestven roman) by Georgi Gospodinov (GG). See also the list of references. The study was carried out in several stages: (1) extraction of examples, containing demo; (2) functional-semantic (for categorisation see section 3) and quantitative analysis of demo in the extracted examples; (3) extraction of the Slovene translation equivalents from the translated novels analysed; (4) functional-semantic and quantitative analysis of the extracted translation equivalents.

\section{The uses of demo (in a contrastive Bulgarian-Slovene perspective)}

The Bulgarian word demo (cf. also the orthographic variant zdemo and the dialect form $\partial e m$; $\mathrm{RBE}, 2006$ ), etymologically linked to the relative adverb *kzde-to 'where' (BER, 1971, p. 234; Kopečný et al., 1980, pp. 166 - 167), has been functionally categorised in various ways: as an adverbconjunction, a relative pronoun-conjunction and a conjunction (e.g. RBE, 2006), an absolute relativizer (a personal relative pronoun and a relative adverb of place) and a conjunction (e.g. Nitsolova, 2008), a complementizer (e.g. Boyadzhiev et al., 1999; for a short presentation see Gadzheva, 2015, p. 409). The main categorisation used in this paper is based on the proposal by Gadzheva (2015, pp. 410 - 413) who very schematically divides the uses of demo into three categories: an absolute relativizer, a subordinator 
(in the case of other connective uses) and other uses (e.g. demo as a part of set phrases or other connectives); other classification possibilities are presented in the analysis itself. The description of demo is complemented (within separate functional-semantic categories) by probable Slovene lexical counterparts. ${ }^{1}$

\section{1. Дemo as an absolute relativiser}

The Bulgarian word demo is considered an absolute relativizer ${ }^{2}$ (absolute because of its grammatical invariability) when it is used as an equivalent of the Bulgarian relative pronouns койmo, която, което (M, F, N sg.) and които (pl.) 'who, which' in attributive clauses (its antecedent can be a subject, a direct or an indirect object; Nitsolova, 1998, pp. 85 - 86; Gadzheva, 2015, pp. 410 - 412; Ivanova and Gradinarova, 2015, p. 272), ${ }^{3}$ cf. (1); demo behaves similarly in predicative clauses (RBE, 2006; cf. Boyadzhiev et al., 1999, p. 360), as illustrated by example (2). Sometimes, the attributive clauses have a concessive meaning - when they emphasize a characteristic of the subject in the main clause which contradicts the whole main clause (RBE, 2006; Ivanova and Gradinarova, 2015, p. 249), cf. (3). In all three cases the Slovene equivalents could be the relative pronouns ki, kateri 'who, which', in the third case also one of the concessive conjunctions, e.g. čeprav 'although' (Herrity, 2000, pp. 106 - 108, pp. 313 - 314; Toporišič, 2004, pp. 341 - 342, p. 444, p. 645; Gabrovšek and Žele, 2019, p. 496, pp. $500-501)$.

(1) Bg: Тоя човек, дето е дохождал, е бил някой просяк. 'That man who came was some beggar' (Yovkov; RBE, 2006). = Sn: Ta človek, ki je prišel, je bil nek berač.

(2) Bg: Ти ли си, дето казваше, че всичко знаеш? 'Are you the one who (lit. who) was saying to know everything?' (Gerov; RBE, 2006). = Sn: Si bil ti, ki je govoril, da vse ve?

(3) Вg: Баба ми, дето е стара жена, не вярва в бога. 'My grandmother, who (although she) is an old woman, does not believe in God' (RBE, 2006). = Sn: Moja babica, ki (̌̈eprav) je stara ženska, ne veruje v Boga.

The attributive clause (e.g. as an interpolation) can also refer to the whole main clause (cf. което 'which, that'; RBE, 2006). A similar meaning in Slovene would be conveyed by the relative pronoun kar 'which' (Herrity, 2000, pp. 105 - 106; Toporišič, 2004, p. 310), cf. (4).

(4) Bg: Остави всичко, па гледай да станеш една ициилизована мадмоазела. - Дето не ще го бъде. 'Leave everything, and make sure to become a civilised mademoiselle. - Which won’t happen' (Voynikov; RBE, 2006). = Sn: Pusti vse in pazi, da postaneš civilizirana gospodična. - Kar se ne bo zgodilo.

\section{2. Дemo as a subordinator}

As a subordinator, demo introduces - functionally and semantically - various types of subordinate clauses. The subordinator $2 e m o^{5}$ introduces relative adverbial clauses of place (including those of direction), competing with e.g. където, де 'where' or propositional phrases в/на който 'in which', cf. $(5-6)$. The construction дето (гдето) - там $u$ 'where - there also' expresses a non

\footnotetext{
${ }^{1}$ The Bulgarian examples (in section 3) are followed by an English gloss and a possible Slovene translation, all by the author of the article.

${ }^{2}$ Cf. relative pronoun-conjunction (RBE, 2006), invariable relative (Nitsolova, 1998, p. 85), complementizer or conjunction (originally relativizer; Boyadzhiev et al., 1999, p. 505, p. 582; cf. Ivanova and Gradinarova, 2015, p. 249). The relativizer demo is typical of colloquial Bulgarian and Bulgarian literary texts (Nitsolova, 1998, p. 85; cf. Gadzheva, 2015, p. 410).

${ }^{3}$ The relativizer demo cannot substitute the relative pronouns when they are used without an antecendent in the main clause (e.g. Който се смее последен, се смее най-добре. 'Hе who laughs last, laughs best'), and when the predicate in the subordinate clause is a compound nominal one (e.g. специалистьт, който си ти (lit.) 'the specialist who you are'; Boyadzhiev et al., 1999, p. 582; Gadzheva, 2015, pp. 411 - 412). When demo functions as an object, it is accompanied by a personal pronoun indicating its syntactic function - it is common in the direct object and obligatory in the indirect object (Gadzheva, 2015, pp. 410 - 411; Ivanova and Gradinarova, 2015, pp. 247, 272).

${ }^{4}$ See Cazinkić (2001,pp. 60 - 70) for a detailed study on the Slovene relativizers ki/kateri and their distribution. ${ }^{5}$ Cf. adverb-conjunction (RBE, 2006), relative pronominal adverb (Lazarova, 1998, p. 146; Boyadzhiev et al., 1999, p. 359), relative adverb and adverbial conjunction (Nitsolova, 1983, p. 458, p. 464).
} 
DOI: https://doi.org/10.37708/ezs.swu.bg.v19i1.4

essential difference (in this case the adverbial clause precedes the main one, and the lower numeral precedes the higher one; Nitsolova, 1983, p. 451; Lazarova, 1998, pp. 146 - 147; Boyadzhiev et al., 1999, p. 359; Gadzheva, 2015, p. 412; cf. Nitsolova, 1998, pp. 85 - 86; RBE, 2006; Ivanova and Gradinarova, 2015, p. 281), cf. (7). The Slovene equivalents of demo 'where' are the relative (adverbial) conjunctions kjer, koder 'id.', kamor 'where, whither', etc., and relative prepositional phrases such as v/na katerem 'in/on which' (Herrity, 2000, pp. 320 - 321; Toporišič, 2004, p. 640; Gabrovšek and Žele, 2019, p. 491).

(5) Bg: Излязох навън пред къщата, дето чакаха жените. 'I went out in front of the house where the women were waiting' (Aleksandrova; RBE, 2006). = Sn: Šel sem ven pred hišo, kjer so čakale ženske.

(6) Bg: Те обичат да пътуват, дето ги води сърието. 'They like to travel where their heart takes them' (Gadzheva, 2015). = Sn: Radi potujejo, kamor jih vodi srce.

(7) Bg: Казахте, че сте четирима, пък сега виждам пет човека. - Нищо, нищо. Дето четири, там и пет. 'You said that there were four of you, but now I see five people. - No problem, no problem. Where there are four, there are (can also be) five' (RBE, 2006). $=\mathrm{Sn}$ : Rekli ste, da ste štirje, sedaj pa vidim pet ljudi. - Nič, nič. Kjer so štirje, jih je (lahko) tudi pet.

Дето can also correspond to the conjunction $ч е$ 'that' when it introduces content clauses (cf. explicative conjunction; Nitsolova, 1983, p. 464; Ivanova and Gradinarova, 2015, p. 249). Objective clauses are found after verbs such as разбирам 'to understand', виждам 'to see', зная 'to know', гледам 'to watch', cf. (8). After verbs or expressions that take indirect objects, objective clauses usually convey a causal meaning; the same meaning can be found in subjective content clauses after impersonal verbs and expressions, ${ }^{6}$ cf. $(9-10)$. The conjunction demo also introduces attributive content clauses, modifying nouns such as факт 'fact', обстоятелство 'circumstance' or accompanying demonstrative pronouns (Nitsolova, 1998, p. 85; Lazarova, 1998, p. 102; Gadzheva 2015, p. 412; RBE, 2006; cf. Nitsolova, 1983, p 451, p. 464), cf. $(11-12)$. The Slovene equivalents of demo in all these cases are the explicative $d a$ 'that' or - in the case of a causal meaning - one of the causal conjunctions, e.g. ker 'because' (Herrity, 2000, pp. 310 - 312; Toporišič 2004, pp. 435 - 436, p. 443, pp. 638 - 640, p. 644; Gabrovšek and Žele, 2019, pp. 492 - 496, p. 499).

(8) Вg: Да, зная, дето нея ще вземеш. 'Yes, I know that you are going to take her' (Gadzheva, 2015). = Sn: Da, vem, da boš vzel njo.

(9) Bg: Ти сбърка, дето не послуша шефа ... 'You made a mistake that (because) you didn't listen to the boss' (Raynov; RBE, 2006). = Sn: Naredil si napako, da (ker) nisi poslušal šefa. (10) Bg: На някой ще се види странно, дето от време на време си говоря сам. 'It will seem strange to someone that from time to time I talk to myself' (Haytov; RBE, 2006). = Sn: Nekomu se bo zdelo čudno, da (ker) občasno govorim sam s sabo.

(11) Bg: Слушай, Никола, аз обичам Елена и никога не ще си простя лекомислието, дето заминах, без да иे се обадя. 'Listen, Nikola, I love Elena and I will never forgive myself the light-mindedness, that I left without calling her' (Petkanov; RBE, 2006). = Sn: Poslušaj, Nikola, jaz ljubim Eleno in si ne bom nikoli oprostil lahkomiselnosti, da sem odšel, ne da bi jo pozdravil. (12) Bg: Това, дето не искаш да се заловиш за някаква работа, ми се вижда подозрително. 'That you don't want to start some kind of job seems suspicious to me' (Sprostranov; RBE, 2006). = Sn: To, da nočeš prijeti za neko delo, se mi zdi sumljivo.

When demo introduces exclusive clauses (their content is to be substituted with the content of the main clause), it coincides with the more literary conjunctions вместо да, наместо $\partial a$ 'instead of' (Nitsolova, 1983, pp. 451, 464; Genadieva-Mutafchieva, 1998, pp. 206 - 207; Gadzheva 2015, p. 412; RBE, 2006; Ivanova and Gradinarova 2015, pp. $366-367) ;{ }^{7}$ its Slovene equivalent would be the

\footnotetext{
${ }^{6}$ According to Lazarova (1998, p. 102), demo is rare in subjective clauses. - Nitsolova (1983, p. 451, p. 465), Petrova (1998, p. 168), and Ivanova and Gradinarova (2015, p. 306) explicitly mention causal clauses introduced by the (spoken-colloquial) conjunction задето (загдето, дето).

${ }^{7}$ The exclusive demo is typical of spoken-colloquial Bulgarian (Genadieva-Mutafchieva, 1998, p. 207).
} 
DOI: https://doi.org/10.37708/ezs.swu.bg.v19i1.4

conjunction namesto da 'instead of' (which is contrastive, according to Herrity, 2000, p. 315; cf. Toporišič, 2004, p. 599; Gabrovšek and Žele, 2019, p. 503), cf. (13).

(13) Вg: Дето ще дрънкаи, по-добре е да станеш и да туриш хляб в торбата. 'Instead of chattering (lit. instead that you chatter), it would be better if you stopped and put the bread in the bag' (Yovkov; RBE, 2006). = Sn: Namesto da čvekaš, je bolje, da se ustaviš in daš kruh $v$ torbo.

More rarely, demo (similar to чe 'that') is found in adverbial clauses of degree (with a meaning of consequence; RBE, 2006; cf. Nitsolova, 1983, p. 451); the corresponding Slovene conjunctions are $d a$, tako - da 'so that', toliko - da 'so much so that' (Herrity, 2000, pp. $314-315$; Toporišič, 2004, pp. 642 - 643; cf. Gabrovšek and Žele, 2019, p. 503), cf. (14).

(14) Bg: Нему тие думи на Тинка тъй се харесаха (...), дето повече не може да бъде. 'Не liked these Tinka's words so much, that more isn't possible' (Vlaykov; RBE, 2006). = Sn: Njemu so bile te Tinkine besede tako v̌̌eč, da bolj ni niti mogoče.

\subsection{Other uses of demo}

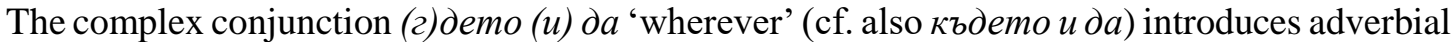
clauses of place with a concessive meaning (Gadzheva, 2015, p. 413; RBE, 2006); in Slovene, a locative-concessive meaning (randomness) would be signaled by the conjunctions kjerkoli, kamorkoli 'wherever' (the latter indicates direction; SSKJ, 1994), cf. (15).

(15) Вg: Дето и да ида - се си ти при мен-жалбо възжелана, дух невъплотен. 'Wherever I go, you are always with me, desired sorrow, unincarnated spirit' (Tserkovski; RBE, 2006). = Sn: Kamorkoli grem - vedno si ti z menoj - žalost tako želena, duh neutelešen.

When (2)дето ( $u$ ) $\partial a$ is followed by the verb съм 'to be' in the present tense or било, the past participle ( $\mathrm{N} \mathrm{sg}$.) of $\mathrm{cb} M$, it has an adverbial meaning 'wherever, anywhere', the same as Slovene kjerkoli, cf. (16).

(16) Bg: Аз няма да работя дето и да е. 'I won't work wherever' (RBE, 2006). = Sn: Jaz ne bom delal kjerkoli.

The complex conjunction освен дето indicates addition-gradation or exclusion. (a) When the main clause is affirmative, the conjunction indicates that the content of the subordinate clause is added to the one in the main clause (it can inidcate also gradation; cf. the synonym освен че 'beside (that), in addition to, not only'); (b) When the main clause includes negation, the subordinate clause introduced by освен дето indicates the only limitation to the negation in the main clause (cf. освен че 'еxсерt that, with the exception of'; Gadzheva, 2015, p. 413; RBE, 2006; Ivanova and Gradinarova, 2015, pp. 349 351); the Slovene equivalents of освен дето would be poleg tega, da 'in addition to' in the first case, and razen $d a$ 'except that, with the exception of' in the second one (SSKJ, 1994; Toporišič, 2004, p. 643; Gabrovšek and Žele, 2019, p. 503), cf. (17-18).

(17) Bg: Освен дето направи много борчове, (Виловски) привикна да гледа твърде либерално на понятието за мое и твое. 'In addition to having run up huge debts, (Vilovski) got used to viewing the concept of mine and yours in a very liberal way' (Georgiev; RBE, 2006). = Sn: Poleg tega, da je nabral veliko dolgov, se je (Vilovski) navadil gledati na koncept mojega in tvojega na zelo liberalen način.

(18) Bg: Не прави нищо, освен дето присъства (...) 'He/she doesn't do anything with the exception of being there' (Gadzheva, 2015). $=$ Sn: Ne dela ničesar, razen da prisostvuje.

The complex conjunction само дето (гдето) also conveys a contrastive meaning. It can indicate either (a) the only limitation to the content of the main clause, or (b) a senseless or an unfounded action with regard to the circumstances, expressed in the previous clause (Gadzheva, 2015, p. 413; RBE, 2006); in Slovene, the same meanings are conveyed by the limitative (restrictive) conjunctions samo 
$d a$, le da 'except that' or the limitative particle samo 'only' in the first case (SSKJ, 1994; Herrity, 2000, pp. 308 - 309; Toporišič, 2004, p. 643), ${ }^{8}$ and expressions such as brez potrebe 'without reason' or zaman 'to no avail' in the second one, cf. $(19-20)$.

(19) Bg: С него си приличаме (...), само дето той е с една глава по-висок от мене. 'Wе look alike, except that he is a whole head taller than me' (Stomin; Gadzheva, 2015). = Sn: $Z$ njim sva si podobna, samo da je za eno glavo višji od mene.

(20) Bg: Само дето ме води на лекар, нищо ми няма. 'He/she is taking me to the doctor without reason, there is nothing wrong with me' (Gadzheva, 2015). = Sn: Zaman me pelje $k$ zdravniku, nič mi ni.

The conjunction demo (as a synonym of както 'as') is found in parenthetical clauses (e.g. demo се вика, дето се казва, дето има една дума 'as it is said; as the saying goes'), signalling that the main clause contains a citation or a well-known fact (Gadzheva, 2015, p. 413; RBE, 2006); its Slovene equivalents, functioning as quotation links, would be the conjunctions kakor and kot 'as' (Kalin Golob, 2000, pp. 5 - 9; Vičar, 2009, p. 121), cf. (21).

(21) Bg: Ти виждал ли си добруджанските жита? Не са жита, а море, край, дето е думата, нямат. 'Have you ever seen the wheat fields of Doburdža? They are not wheat fields, but a sea, they don't have, as they say, an end' (Gulyashki; RBE, 2006). = Sn: Ti si že videl dobruška žitna polja? To niso polja, ampak morje, konca, kot pravijo, nimajo.

In addition, RBE (2006) mentions the archaic explanatory set phrase demo me ( $\partial$ a ce) peчe (or каже) 'that is to say, i.e.', corresponding to the Slovene conjunction to je 'i.e.' or the set phrase to pomeni (da) 'that means (that)' (cf. expository elaboration in Skubic, 1999, pp. 217 - 218; see also Herrity, 1999, pp. 305 - 306; Toporišič, 2004, pp. 441, 648), cf. (22).

(22) Bg: Защо са цветът и семената? - За да се размножават растенията. Дето ще рече, иветът и семената са органи за размножение. 'What is the purpose of the bloom and the seeds? - For the plants to reproduce. That is to say, the bloom and the seeds are reproductive organs' (RBE, 2006). = Sn: Zakaj so cvet in semena -Da se rastline razmnožujejo. To pomeni, da so cvet in semena razmnoževalni organi.

\section{The Slovene translation equivalents of demo}

In the five novels analysed, demo is found 59 times ( $\mathrm{PV}=29 ; \mathrm{DD}=12 ; \mathrm{GG}=11 ; \mathrm{HO}=5 ; \mathrm{BD}$ $=2$ ). Its occurrences can be subdivided into seven categories, based on their function and meaning, ${ }^{9} \mathrm{cf}$. дemo as an absolute relativizer, a relativizer with a concesssive meaning, a conjunction of place and a causal conjunction; in the source texts, demo is also part of two complex conjunctions - the limitative освен дето and the limitative-adversative само дето, which in a few cases indicates an unfounded (unexpected) action; in addition, дето occurrs as part of the parenthetical clause дето се казва. In Slovene translations, within separate functional-semantic categories, demo is usually rendered in different ways. ${ }^{10}$

4.1 In the analysed texts, the most frequent use of demo (with 29 occurrences; DD $=9 ; \mathrm{PV}=$ $10 ; \mathrm{HO}=3 ; \mathrm{GG}=7$ ) is that of an absolute relativizer which introduces attributive clauses. ${ }^{11}$ Its most frequent Slovene translation equivalent ( 23 occurrences) is the relative pronoun $k i$ 'who; which' (as a subject and direct object), functionally similar to demo; two times $k i$ is accompanied by the pronoun tisti 'the one, that', cf. (23-24). A similar equivalent to ki is kateri 'who' (one occurrence) functioning as a prepositional object, cf. (25).

\footnotetext{
${ }^{8}$ The conjunctions le da and samo da indicate exclusion, according to Toporišič (2004, p. 643).

${ }^{9}$ The analysis in section 4 follows the functional-semantic categorization in section 3 .

${ }^{10}$ In section 4, the Bulgarian examples and their Slovene translations are accompanied by English glosses (translated by the author of the article) to indicate the relation between the source text form (дето, освен дето, само деmo) and its translation equivalent.

${ }^{11}$ In four cases (DD = 2; PV = 2), the relative attributive clause is separated from the main clause.
} 
(23) Bg: Даже аз му свих едни чистачки от колите, дето ги паркират у нас (...) 'Even I

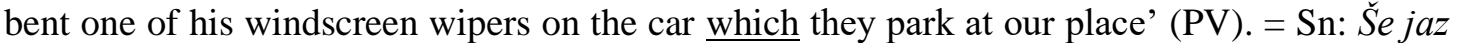
sem mu odtrgala brisalnike $z$ avtomobila, ki ga parkirajo pri nas (...) 'Even I ripped off his windscreen wipers on the car which they park at our place' ( $\left.\mathrm{PV}^{\mathrm{S}}, 264\right)$.

(24) Bg: Най-големия ... ти го знаеш ... дето учи в града 'The oldest one ... you know him ... who studies in the city' (DD). = Sn Največjega ... saj veš, kateri je to. Tisti, ki se uči v mestu 'The oldest one ... you know who it is. The one that studies in the city' $\left(\mathrm{DD}^{\mathrm{S}}, 518\right)$.

(25) Bg: (...) и казваш неща, дето друг път не би си и помислил 'and you say things which you wouldn't consider on other occasions' $(\mathrm{GG}) .=\mathrm{Sn}:(. .$.$) in poveš stvari, na katere sicer ne$ bi niti pomislil 'and you say things which you wouldn't think about otherwise' $\left(\mathrm{GG}^{\mathrm{S}}, 25\right)$.

In two cases ( $\mathrm{DD}=2$ ), the Bulgarian relativizer demo is translated with a null subject, cf. (26). All the other translation equivalents occur only once and show a semantic deviation from the source function: the consecutive conjunction $d a$ 'that'; the parenthetic commentary kot pravite 'as you say'; the interrogative pronoun $k d o$ 'who', which corresponds to a complex source text segment (larger than a clause), containing the relativizer demo, cf. $(27-29)$.

(26) Bg: Видии ли оня тал, с червената коса, дето отнася балите? 'Do you see the one there, with red hair, who is carrying the bales?' (DD). = Sn: Vidiš tistega rdečelasca, $\emptyset$ zdajle nese balo? 'Do you see that redhead, just now he's carrying a bale?' (DD $\left.{ }^{\mathrm{S}}, 349\right)$.

(27) Bg: (...) какви са тия учени, дето не знаят едно най-обикновено пиле? 'what are these scientists who don't even know the most ordinary bird?' (PV). = Sn: Kakšni so ti znanstveniki, da ne poznajo niti najnavadnejše ptice? 'What are these scientists that don't even know the most ordinary bird?' (PV, 174$)$.

(28) Bg: А имате ли и някакво подобно вино?... Дето не всякога и всекиму? 'Do you also have some kind of similar wine? ... Which is not for every day and for everyone?' (PV). = Sn: Imate tudi kakšno podobno vino? ... Kot pravite, ne zmeraj in ne za vsakogar? 'Do you also have some kind of similar wine? ... As you say, not always and not for everyone?' ( $\left.\mathrm{PV}^{\mathrm{S}}, 388\right)$. (29) Bg: Какъв е тоя, дето вика? 'Who is this one that is shouting?' (DD). = Sn: Kdo tam vpije? 'Who is shouting there?' $\left(\mathrm{DD}^{\mathrm{S}}, 184\right)$.

4.2 Two occurrences $(\mathrm{PV}=2)$ of the relativizer demo have a concessive meaning, which is lost in both Slovene translation counterparts: the causal complex (phrasal) conjunction zato ker 'because' and an omission (of the whole subordinate clause), cf. (30-31).

(30) Bg: Аз ли съм егоист? /.../ Дето ви мъкна цяло лято с колата на вуйчо? 'Am I an egoist? Although I have been driving you the whole summer with my uncle's car?' (PV). = Sn: Jaz da sem egoist? /.../ Zato, ker vas vse poletje prevažam z ujčevim avtomobilom? 'I am an egoist? Because I have been driving you the whole summer with my uncle's car?' ( $\left.\mathrm{PV}^{\mathrm{s}}\right)$.

(31) Вg: И хипитата, дето са хипита, и те предпочитат да се излежават на Пикадили съркъс (...) 'Even hippies, despite being hippies, also prefer to lounge around in Piccadilly Circus' (PV). = Sn: Še hipiji Ø rajši poležavajo na Piccadillyju 'Even hippies prefer to lounge around in Piccadilly Circus' (PV, 113$)$.

4.3 Three times $(\mathrm{GG}=1, \mathrm{BD}=1, \mathrm{PV}=1)$, demo introduces an adverbial clause of place, which is preserved in only one target text, with the relative adverbial conjunction kjer 'where' functioning as a connective element, cf. (32); the two remaining Slovene translation solutions are omissions (the source text segment has been rearranged), cf. (33).

(32) Вg: Да идем нейде, дето нищо не си строил! 'Let's go somewhere where you haven't built anything' (BD). = Sn: Pojdiva kam, kjer nisi ničesar gradil! 'Let's go somewhere where you didn't build anything' (BD $\left.{ }^{\mathrm{S}}, 458\right)$.

(33) Bg: Родих ся на 1632 г. в градът Йорк, дето бама ми (който изнапреди беше търговеи в Хулло) беше ся отеглил, откак спечели добри пари и напуснал бе вече търговията. 'I was born in 1632 in the town of York where my father (who had been a merchant in Hull before that) had withdrawn after he had earned good money and had already abbandoned the trade' (GG). = Sn: Rodil sem se leta 1632 v mestu York $\emptyset v$ dobri družini, 
DOI: https://doi.org/10.37708/ezs.swu.bg.v19i1.4

čeprav ni bila iz te dežele, zakaj moj oče je bil prišlek iz Bremna in se je najprej naselil v Hullu. Pridobil si je lepo premoženje s trgovino, ko pa je opustil ta poklic, se je nastanil v Yorku. 'I was born in 1632 in the town of York in a good family, although it was not from this country, since my father was a newcomer from Bremen and he had first settled in Hull. He had earned a good fortune with trade, and when he left this profession, he settled in York' $\left(\mathrm{GG}^{\mathrm{S}}, 21\right)$.

4.4 Ten occurrences of demo $(\mathrm{OH}=2 ; \mathrm{GG}=2 ; \mathrm{BD}=1 ; \mathrm{PV}=5)$ show a causal semantics. ${ }^{12}$ Five times the causal demo is translated with the Slovene clausal conjunction ker 'because', cf. (34); in four cases, the Slovene equivalent of the subordinate clause with demo is an omission, the result of which are different structural-semantic changes, cf. for example (35) with the merger of the main and the subordinate clause ${ }^{13}$ in one case, demo with a causal-illustrative (comparative) meaning ('as') is translated with the Slovene illustrative particle denimo 'for example', cf. (36).

(34) Вg: Вуйчо, разсърди ли се, дето намери тая тайфа във вилата? 'Uncle, did you get angry, because you found this bunch in the house?' (PV). = Sn: Si hud, ker si našel to druščino $v$ hiši? 'Are you angry, because you found this bunch in the house?' $\left(\mathrm{PV}^{\mathrm{S}}, 135\right)$.

(35) Bg: He е на добро, дето е домел! 'It's not good that he has arrived' (BD). = Sn: Nič dobrega nam ni prinesel! 'He hasn't brought us anything good' $\left(\mathrm{BD}^{\mathrm{S}}, 129\right)$.

(36) Bg: Никога лете. Дето викал един, за умиране ли е сега, толкова работа ме чака ... 'Never in the summer. Because one said, is it time for dying, so much work awaits me' (GG). = Sn: Nikoli poleti. Eden je denimo rekel, ali se zdaj umira, toliko dela me čaka ... 'Never in the summer. One said for example, is it time to die now, so much work awaits me' (GG $\left.{ }^{\mathrm{S}}, 129\right)$. 4.5 The analysed Bulgarian novels include two examples $(\mathrm{PV}=2)$ of the conjunction освен demo signalling the limitation to the negated content of the main clause; the Slovene translation counterparts razen da, le da 'except that, with the exception of' preserve the limitative semantics of the source text element, cf. $(37-38)$.

(37) Bg: Не, нищо не бе забравил, освен дето не я целуна. 'No, he didn't forget anything with the exception of kissing her' (PV). = Sn: Ne, ničesar ni pozabil, razen da je ni poljubil 'No, he didn't forget anything with the exception of kissing her' (PV', 302).

(38) Bg: За една година нищо не се бе променило в тях, освен дето сега по-често пресягаха към чашките. (...) 'In one year they hadn't changed at all, except that now they were more frequently reaching for the glasses' $(\mathrm{PV}) .=\mathrm{Sn}$ : Po letu dni se niso čisto nič spremenile, le da so zdaj pogosteje segale po kozarcih (...) 'After a year they hadn't changed a bit, except that now they were more frequently reaching for the glasses' (PV $\left.{ }^{\mathrm{S}}, 416\right)$.

4.6 Another complex conjunction containing demo in the analysed Bulgarian novels is само demo with 11 occurrences ( $\mathrm{DD}=1 ; \mathrm{GG}=1 ; \mathrm{PV}=9) .{ }^{14}$ In nine cases the conjunction camo demo has a limitative-adversative meaning (cf. 'except that, but'); its most frequent equivalent (with five occurrences) is the limitative particle samo 'only', cf. (39); the other equivalents (one occurrence each) are the adversative conjunctions pač pa and vendar pa 'but', the modal-adversative phrase žal pa 'but unfortunately', and a comparative-limitative conjunction kakor da 'than' (in combination with drugače 'differently'), cf. (40 - 43). In the two remaining examples, caмo demo indicates an unfounded or an unexpected action (close to happening) with regard to the action in the previous clause; its Slovene translations are the adverb zaman 'to no avail' and the modal particle skoraj 'almost', cf. (44 - 45).

(39) Вg: Трабант като трабант, само дето иелият бе покрит с керемидената екзема на замазките. 'Trabant as a Trabant, only it was completely covered with the tile eczema of the paste' $(\mathrm{PV}) .=\mathrm{Sn}$ : Bil je pač trabant, samo ves pokrit z opečnatimi izpuščaji premazov. 'It was just a trabant, only completely covered with tile eczema from the paste' ( $\left.\mathrm{PV}^{\mathrm{s}}, 283\right)$.

\footnotetext{
${ }^{12}$ In two cases (GG, PV), the subordinate clause, introduced by demo, is separated from the main clause.

${ }^{13}$ The other structural-semantic changes include: the subordinate clause becomes an independent one $\left(\mathrm{OH}^{\mathrm{S}}, 144\right)$; the subordinate clause becomes an adversative coordinate clause indicating substitution ( $\left.\mathrm{PV}^{\mathrm{S}}, 262\right)$; the causal semantics of the clause is preserved but without an explicit connective element ( $\left.\mathrm{PV}^{\mathrm{S}}, 386\right)$.

${ }^{14}$ In five cases (DD = 1; PV = 4), the clause introduced by caмo demo occurs independently.
} 
(40) Bg: Ти не си нервна, само дето си малко по-чувствителна. 'You are not nervous, but just a bit more sensitive' (PV). = Sn: Ti nisi živčna, pač pa si precej občutljiva. 'You are not nervous, but quite sensitive' (PV, 258$)$.

(41) Bg: Това той разбра още като му отвори вратата, облечена в много тънка лилава блузка. Само дето лиието иे не беше много приветливо. 'Hе realized that as soon as she opened the door, dressed in a very thin blouse. But her face was not very affable' $(\mathrm{PV}) .=\mathrm{Sn}$ : Tega se je zavedel že tisti trenutek, ko mu je Donka, oblečena v tanko, višnjevo bluzo, odprla vrata. Vendar pa ji obraz ni bil preveč prijazen. 'He realized that the moment when Donka, dressed in a thin cherry blouse, opened the door. But her face was not too affable' (PV, 277$)$.

(42) Bg: (...) вече бе взела решение - трябва да говори със Сашо. Само дето не знаеше служебния му телефон. 'she had already taken a decision - she must speak with Sasho. But she didn't know his office telephone number' (PV). = Sn: (...) je že napravila sklep - pogovoriti se mora s Sašem. Žal pa ni imela njegovega službenega telefona 'she had already drawn a conclusion - she must talk with Sašo. But unfortunately she didn't have his office telephone number' $\left(\mathrm{PV}^{\mathrm{s}}, 272\right)$.

(43) Bg: Криста изобщо не го усещаше, само дето бе прибавила и неговия глад към своя, тъй че добре си похапваше. 'Krista couldn't feel him at all, except that she had added his hunger to her own, therefore she was eating well' (PV). = Sn: Ni ga čutila drugače, kakor da je bila tudi zanj lačna in je torej krepko jedla. 'She didn't feel him differently than to be hungry for him as well, and therefore she ate well' (PV', 362).

(44) Bg: И без това никой няма да им повярва, само дето ще се изложат. 'Anyway, nо one will believe them, they will only expose themselves in vain' $(\mathrm{PV}) .=\mathrm{Sn}$ : Nihče jim ne bi verjel, zaman bi se izpostavljali 'No one would believe them, they would expose themselves to no avail' $\left(\mathrm{PV}^{\mathrm{s}}, 243\right)$.

(45) Bg: Тия думи имаха за цел да дразнят противника, а ние само дето не скачахме от радост в леглата. 'These words were meant to irritate the opponent, we, on the other hand, were nearly jumping for joy in the beds' $(\mathrm{GG}) .=$ Sn: Cilj teh besed je bilo živciranje nasprotnika, midva pa bi od radosti skoraj skočila vsak iz svoje postelje. 'The goal of these words was to irritate the opponent, each of us two, on the other hand, almost jumped out of our beds' $\left(\mathrm{GG}^{\mathrm{S}}, 120\right)$.

4.7 In two cases $(\mathrm{DD}=2)$, the conjunction demo is part of the parenthetical clause demo ce казва 'as the saying goes'; in one case, cf. (46), the source structure is preserved - with the comparative conjunction kakor 'as' functioning as the Slovene equivalent of demo; in the other case, the parenthetical clause is omitted in translation, cf. (47).

(46) Bg: Хляба, дето се казва, от дете само си го е изкарвало като аргатче ... 'The bread, $\underline{\text { as }}$ the saying goes, he earned it from childhood as a labourer' (DD). = Sn: Že od otroških let si je, kakor pravimo, sam služil svoj kos kruha 'From childhood, as we say, he earned his daily bread on his own' (DD $\left.{ }^{\mathrm{S}}, 519\right)$.

(47) Bg: На черква да идем, дето се казва, няма с какво свеш да запалим ... 'If we go to church, as the saying goes, we don't have any money to light a candle' (DD). = Sn: Če hočemo $v$ cerkev, $\emptyset$ ni denarja za sveče, da bi jih prižgali ... 'If we want to go to church, there's no money to light the candles' $\left(\mathrm{DD}^{\mathrm{S}}, 303-304\right)$.

\section{Discussion and conclusion}

The aim of the article was to determine and to functionally-semantically and quantitatively analyse translation equivalents of the Bulgarian word demo in Slovene translations of five Bulgarian novels published in the second half of the 20th century.

In the analysed texts, demo is found 59 times - its most frequent function is that of the absolute relativizer (29 occurrrences), followed by demo as a causal conjunction (10 occ.), an adverbial conjunction of place ( 3 occ.) and a relativizer with a concessive meaning $(2 \mathrm{occ}$.); demo occurs also as a part of two complex conjunctions: само demo, indicating limitation-contrast (9 осc.) or unfoundedness ( 2 осc.), and the limitative освен дето ( 2 осc.); in two cases demo is found in the parenthetical clause дето се казва 'as the saying goes'. There are no other uses of дето (cf. section 3) in the novels analysed. 
DOI: https://doi.org/10.37708/ezs.swu.bg.v19i1.4

In the case of demo as an absolute relativizer ( 29 occ.), the most frequent Slovene translation equivalents are the functionally-semantically analogous relative pronouns $k i$ 'who; which' ( $23 \mathrm{occ}$.), kateri 'who' $(1 \mathrm{occ}$.) and the combination of a demonstrative and a relative pronoun tisti, $k i$ 'the one that' (2 occ.). Other translation solutions include null subjects ( 2 occ.), the consecutive conjunction $d a$ 'that', the parenthetic clause kot pravite 'as you say', and the interrogative pronoun kdo 'who', which substitutes a complex source text segment, containing the relativizer demo $(1 \mathrm{occ}$. each); the last five solutions clearly differ - in terms of their functional-semantic features - from the source text elements. The same can be said of both Slovene translation equivalents - an omission and a causal conjunction zato ker 'because' - of the concessive relativizer demo ( 2 occ.). The causal conjunction demo $(10 \mathrm{occ}$.) has been translated with the Slovene causal conjunction ker 'because' in half of all the cases; the remaining translations include four omissions (resulting in different structural-semantic changes) and the illustrative particle denimo 'for example'. Out of three examples of demo as an adverbial conjunction of place only one has been rendered with a functionally-semantically analogous Slovene conjunction kjer 'where', in the other two cases the adverbial clause of place has been omitted in the translation. The Slovene translation equivalents of the limitative-adversative conjunction само demo (9 occ.) preserve its meaning, cf. the limitative particle samo 'only' ( $5 \mathrm{occ}$.), the adversative conjunctions pač pa and vendar pa 'but', the modal-adversative phrase žal pa 'but unfortunately', and a comparativelimitative conjunction kakor da 'that' (combined with the adverb drugače 'differently'; 1 occ. each). In two cases, само demo indicates that the action in the subordinate clause is unfounded or unexpected with respect to the content of the main clause - both Slovene translation equivalents have comparable semantic features, cf. the adverb zaman 'to no avail' and the modal particle skoraj 'almost'.

The two translations of the limitative conjunction освен дето make use of semantically similar conjunctions razen $d a$ and le $d a$ 'except that, with the exception of'. As already mentioned, demo is also found in two cases of the parenthetical clause дето се казва 'as the saying goes', in which it functions as a quotation link (introducer); the parenthetical clause has been preserved in only one translation, cf. kakor pravimo 'as we say', with the conjunction kakor 'as' as the translation equivalent of demo; the other translation solution is an omission.The analysis has shown that the Slovene target texts include a wide range of translation solutions for Bulgarian дето, само дето and освен дето (within separate functional-semantic categories). In most cases (approx. three quarters), the Slovene translations preserve the functional-semantic features of the source text elements, cf. above all the equivalents of само дето and освен дето. Nevertheless, in approx. one quarter of all cases (or almost a third, if we exclude the equivalents of само дето and освен дето), the translation equivalents display evident semantic changes with respect to the source text elements, cf. different Slovene translation equivalents of demo as an absolute relativizer, a "concessive" relativizer, a causal conjunction, a conjunction of place and a quotation link. Moreover, the Slovene translation counterparts of Bulgarian дето, само дето and освен дето exhibit not only functional-semantic shifts, but also lexical and structural changes, since they consist of pronouns, conjunctions, omissions, modal particles, adverbs and clauses. In the analysed Bulgarian novels, demo has a broad array of uses (even though not all of the possible uses, cf. section 3 , are present), which were rendered with an even greater multitude of equivalents in Slovene translations. This is probably due to the absence of a comparable Slovene lexical item (despite the existence of multifunctional conjunctions in Slovene; for a short overview see Toporišič, 2004, pp. 434 - 436), and to the fact that translators time and again - intentionally or unintentionally - depart from the semantic, syntactic and stylistic features of the source text. Although the article indicates the main functional-semantic features of дето, само дето and освен дето, their possible lexical equivalents in Slovene and actual translation equivalents in Slovene translations of five Bulgarian novels, a more representative insight would demand a larger and a more varied corpus. Furthermore, such a corpus would allow us to investigate other issues as well, e.g. the frequency of demo and its functions in different text types, its translation equivalents across different genres, the translators' tendencies in dealing with дето (само дето and освен дето included), etc. These aspects remain to be addressed in future research.

BIBLIOGRAPHY: 
DOI: https://doi.org/10.37708/ezs.swu.bg.v19i1.4

БЕР (1971)

Бояджиев, Т., Куцаров, И., Пенчев, Й. (1999)

Вежинов, П. (1981)

Гаджева, С. (2015)

ГенадиеваМутафчиева, 3. (1998)

Господинов, Г. (1999)

Дачева, $Г$.,

Тишева, Й. (2005)

Димитрова, Б. (1965)

Димов, Д. (1951)

Иванова, Е. Ю., Градинарова, А. А. (2015)

Лазарова, А. (1998)

Ницолова, Р. (1983)

Ницолова, Р. (1998)

Ницолова, Р. (2008)
Български етимологичен речник, т. 1 (А - 3). Ред. Вл. И. Георгиев. София: БАН, ИБЕ, Издателство на БАН, 679 с. (BЕR (1971) - Balgarski etimologichen rechnik, t. 1 (A - Z). Red. Vl. I. Georgiev. Sofiya: BAN, IBE, Izdatelstvo na BAN, 679 s.)

Съвременен български език. София: Петър Берон, 655 с. (Boyadzhiev, T., Kutsarov, I. and Penchev, $Y$. Savremenen balgarski ezik. Sofiya: Petar Beron, 655 s.)

Нощем с белите коне (PV). Пловдив: Христо Г. Данов. (26.5.2020) $<$ https://chitanka.info > (Vezhinov, P. Noshtem s belite kone (PV). Plovdiv: Hristo G. Danov. (26.5.2020) <https://chitanka.info >)

Българското езикознание във Франция между книжовната норма и разговорни практики. Пример с употребата на дето. - В: Научни перспективи на съвременната българистика 2. Будапеща: Български културен форум, Катедра „Славянска филология““, Университет „Л. Йотвьош“, Българско самоуправление в Кечкемет, с. 408 - 414. (Gadzheva, S. Balgarskoto ezikoznanie vav Frantsiya mezhdu knizhovnata norma i razgovorni praktiki. Primer s upotrebata na deto. - V: Nauchni perspektivi na savremennata balgaristika 2. Budapest: Bolgár Kulturális Fórum, ELTE BTK Szláv Filológiai Tanszék, Kecskeméti Bolgár Önkormányzat, pp. $408-414$.

Сложно съставно с подчинено обстоятелствено изречение за изключване. - В: Граматика на съвременния български книжовен език. Том трети. Синтаксис. Част втора. София: Абагар, с. 206 - 211. (Genadieva-Mutafchieva, Z. Slozhno sastavno s podchineno obstoyatelstveno izrechenie za izklyuchvane. - V: Gramatika na savremenniya balgarski knizhoven ezik v tri toma. Tom treti. Sintaksis. Chast vtora. Sofiya: Abagar, s. 206 - 211.)

Естествен роман (GG). София: Корпорация Развитие. (26.5.2020)<www.slovo.bg> (Gospodinov, G. Estestven roman (GG). Sofiya: Korporatsiya razvitie. (26.5.2020) $\langle$ www.slovo.bg $>$ )

Традицията в разговорните модели - който или дето. - В: Юбилеен славистичен сборник. Благоевград: Югозападен университет „Неофит Рилски“, с. 390 - 399. (Dacheva, G., Tisheva, Y. Traditsiyata v razgovornite modeli - koyto ili deto. - V: Yubileen slavistichen sbornik. Blagoevgrad: Yugozapaden universitet "Neofit Rilski", s. $390-399$.

Пътуване към себе си (BD). София: Български писател. (26.5.2020) $<$ https://chitanka.info > (Dimitrova, B. Patuvane kam sebe si (BD). Sofiya: Balgarski pisatel. (26.5.2020) <https://chitanka.info $>)$

Тютюн (DD). София: Труд. (26.5.2020) <https://chitanka.info $>$ (Dimov, D. Tyutyun (DD). Sofiya: Trud. (26.5.2020) <https://chitanka.info $>$ )

Синтаксическая система болгарского языка на фоне русского. Москва: Языки славянской культуры, 626 с. (Ivanova, E. Yu., Gradinarova, A. A. Sintaksicheskaya sistema bolgarskogo yazyka na fone russkogo. Moskva: Yazyki slavyanskoy kul'tury, $626 \mathrm{s.})$

Сложно съставно с подчинено подложно изречение. - В: Граматика на съвременния български книжовен език. Том трети. Синтаксис. Част втора. София: Абагар, с. 99 - 103. (Lazarova, A. Slozhno sastavno s podchineno podlozhno izrechenie. - V: Gramatika na savremenniya balgarski knizhoven ezik v tri toma. Tom treti. Sintaksis. Chast vtora. Sofiya: Abagar, s. $99-103$.)

Съюз. - В: Граматика на съвременния български книжовен език. Том II. Морфология. София: БАН, ИБЕ, Издателство на БАН, с. 446 - 466. (Nitsolova, $R$. Sajuz. - V: Gramatika na savremenniya balgarski knizhoven ezik. Tom II. Morofologiya. Sofiya: BAN, IBE, Izdatelstvo na BAN, s. 446 - 466.)

Сложно съставно с подчинено определително изречение. - В: Граматика на съвременния български книжовен език. Том трети. Синтаксис. Част втора. София: Абагар, с. 79 - 99. (Nitsolova, R. Slozhno sastavno s podchineno opredelitelno izrechenie. - V: Gramatika na savremenniya balgarski knizhoven ezik v tri toma. Tom treti. Sintaksis. Chast vtora. Sofiya: Abagar, s. 79 - 99.)

Българска граматика. Морфология. София: Университетско издателство „Св. Климент Охридски“, 523 c. (Nitsolova, R. Balgarska gramatika. Morfologiya. Sofiya: Universitetsko izdatelstvo "Sv. Kliment Ohridskc", 523 s.) 
Оливер, Х. (1963)

Петрова, С. (1998)

PБE (2006)

Cazinkić, R. (2001)

Dimitrova, B. (1971)

Dimov, D. (1966)

Gabrovšek, D.,

Žele, A. (2019)

Gospodinov, G. (2005)

Herrity, P. (2000)

Kalin Golob, M.

(2000)

Kopečný, F.,

Šaur, V.,

Polák, V. (1980)

Oliver, H. (1965)

Sandfeld, K. (1968)

Skubic, A. (1999)

SSKJ (1994)

Toporišǐ̌, J. (2004)

Valčanova, M. (2002)

Vežinov, P. (1981)

Vičar, B. (2009)
Федерация на династронавтите (НО). София: Народна младеж. (26.5.2020) $<\underline{\text { https://chitanka.info }}>$ (Haim, $O$. Federatsiya na dinastronavtite $(\mathrm{OH})$. Sofiya: Narodna mladezh. (26.5.2020) <https://chitanka.info $>$ )

Сложно съставно с подчинено обстоятелствено изречение за причина. - В: Граматика на съвременния български книжовен език. Том трети. Синтаксис. Част втора. София: Абагар, с. 162 - 172. (Petrova, S. Slozhno sastavno s podchineno obstoyatelstveno izrechenie za prichina. - V: Gramatika na savremenniya balgarski knizhoven ezik v tri toma. Tom treti. Sintaksis. Chast vtora. Sofiya: Abagar, s. $162-$ 172.)

Речник на българския език, т. 3 (г - деятел). Гл. Ред. К. Челакова. София: БАН, ИБЕ, Академично издателство „Марин Дринов“, ЕТ Емас, 805 с. (26.5.2020) <https://ibl.bas.bg/rbe/> (RBE (2006) - Rechnik na balgarskiya ezik, t. 3 (g-deyatel). Gl. red. K. Chelakova. Sofiya: BAN, IBE, Akademichno izdatelstvo "Marin Drinov", ET Emas, 805 s. (26.5.2020) <https://ibl.bas.bg/rbe/>)

Kategorizacija in razvrstitev oziralnikov ki in kateri. // Slavistična revija, letn. 49, št. 1 -2 , pp. $55-73$.

Na poti k sebi $\left(\mathrm{BD}^{\mathrm{S}}\right)$. Prev. K. Špur. Ljubljana: DZS, 474 p.

Tobak $\left(D^{S}\right)$. Prev. K. Špur. Ljubljana: CZ, 869 p.

Tipologija stavčnočlenskih odvisnikov v slovenščini. // Slavistična revija, letn. 67, št. 3 , pp. $487-507$.

Naravni roman $\left(\mathrm{GG}^{\mathrm{S}}\right)$. Prev. B. Omerzel. Ljubljana: Študentska založba, 167 p.

Slovene: A Comprehensive Grammar. London/New York: Routledge, 372 p.

Razvoj sklicevalnih avtomatizmov v prvem slovenskem dnevniku. // Slavistična revija, letn. 48 , št. 1 , pp. $1-26$.

Etimologický slovník slovanských jazyků. Slova gramatická a zájmena. Sv. 2: spojky, částice, zájmena a zájmenná adverbia. Praha: Academia, 783 p.

Federacija dinastronavtov $\left(\mathrm{OH}^{\mathrm{S}}\right)$. Prev. M. Rode. Ljubljana: MK, 166 p.

Linguistique balcanique. Problèmes et résultats. Paris: Libraire C. Klincksieck, 242 p. Ogled kohezijske vloge slovenskega členka. // Slavistična revija, letn. 47, št. 2, pp. 211 -238 .

Slovar slovenskega knjižnega jezika. Ur. A. Bajec et al. Ljubljana: SAZU, ZRC SAZU, ISJFR, DZS, 1714 p.

Slovenska slovnica. Maribor: Obzorja, 923 p.

Raziskave o slovenskem jeziku v bolgarski jezikoslovni tradiciji - zgodovina in perspektive. - In: Historizem v raziskovanju slovenskega jezika, literature in kulture (Obdobja 18). Ljubljana: Center za slovenščino kot drugi/tuji jezik pri Oddelku za slovanske jezike in književnosti FF, pp. 389 - 400.

Ponoči z belimi konji (PV ${ }^{\mathrm{S}}$ ). Prev. K. Špur. Maribor: Obzorja, 418 p.

Zgodovinskorazvojni pregled pojmovanja vrinjenega stavka (parenteze) $\mathrm{v}$ slovenističnem jezikoslovju. // Jezikoslovni zapiski, letn. 15, št. 1 - 2, pp. 113 - 126. 